\title{
Pseudo-nitzschia kodamae sp. nov. (Bacillariophyceae), a toxigenic species from the Strait of Malacca, Malaysia
}

\author{
Sing Tung Teng ${ }^{a}$, Hong Chang $\operatorname{Lim}^{\mathrm{a}}$, Po Teen Lim ${ }^{\mathrm{b}}$, Viet Ha Dao ${ }^{\mathrm{c}}$, Stephen S. Bates ${ }^{\mathrm{d}}$, \\ Chui Pin Leaw ${ }^{\mathrm{b}, *}$ \\ ${ }^{a}$ Faculty of Resource Science and Technology, Universiti Malaysia Sarawak, Kota Samarahan, 94300 Sarawak, Malaysia \\ ${ }^{\mathrm{b}}$ Bachok Marine Research Station, Institute of Ocean and Earth Sciences, University of Malaya, Bachok, 16310 Kelantan, Malaysia \\ 'Institute of Oceanography, VAST, 01 Cau Da, Nha Trang, Vietnam \\ ${ }^{\mathrm{d}}$ Fisheries and Oceans Canada, Gulf Fisheries Centre, P.O. Box 5030, Moncton, NB, Canada E1C 9B6
}

\section{A R T I C L E I N F O}

\section{Article history:}

Received 17 January 2014

Received in revised form 12 February 2014

Accepted 12 February 2014

\section{Keywords:}

Domoic acid

Malacca Strait

Malaysia

Pseudo-nitzschia

P. kodamae

\begin{abstract}
A B S T R A C T
A recent field survey of Pseudo-nitzschia species from coastal waters of Malaysia demonstrated the presence of a novel morphotype, $P$. sp. Port Dickson, in the Strait of Malacca. In this study, we revisited the site and established five clonal cultures of this morphotype, assessed the strains' morphology and genetics, and delineated it as a novel species. As observed by electron microscopy, these strains showed morphological features identical to those of the previous field specimens designated as $P$. sp. Port Dickson. The cells differ from other Pseudo-nitzschia species in the P. pseudodelicatissima complex sensu lato by their lower densities of fibulae, striae and band striae in $10 \mu \mathrm{m}$. Molecular data of the nuclear encoded large subunit ribosomal rRNA gene and the internal transcript spacer region (ITS) further supported the delineation of this novel lineage. Based on both morphological and molecular data, $P$. sp. Port Dickson is considered to represent a new species, for which we propose the name Pseudo-nitzschia kodamae sp. nov. Production of domoic acid (DA) in the strains was examined by FMOC-LC-FLD. Only strains of $P$. kodamae were observed with a peak corresponding to DA, giving a concentration of 1.2$42.5 \mathrm{pg}$ DA cell ${ }^{-1}$. Screening of Pseudo-nitzschia caciantha, Pseudo-nitzschia batesiana, Pseudo-nitzschia fukuyoi and Pseudo-nitzschia lundholmiae cultures from the same waters, however, showed no detectable DA. This is the first report of a potentially toxigenic Pseudo-nitzschia species from the region.
\end{abstract}

(c) 2014 Elsevier B.V. All rights reserved.

\section{Introduction}

The genus Pseudo-nitzschia H. Peragallo is a group of pennate chain-forming diatoms, of which at least 15 species produce the toxin domoic acid (DA), responsible for amnesic shellfish poisoning (ASP) (reviewed in Lelong et al., 2012; Fernandes et al., 2014). The species are found in coastal and oceanic waters across the world's oceans, including the Southern Ocean of Antarctica (Lelong et al., 2012). The tropics are considered to be a hotspot of biodiversity, but interestingly, the few available studies of the occurrence and diversity of Pseudo-nitzschia species in the region show that these occur less frequently and at a lower diversity compared to temperate and cold waters (reviewed in Trainer et al., 2012). The

\footnotetext{
Abbreviations: DA, domoic acid; ITS2, the second internal transcript spacer; LSU rDNA, large subunit ribosomal DNA; CBC, compensatory base change; HCBC, hemicompensatory base change; FMOC-LC-FLD, 9-fluorenylmethylchorofromate, with fluorescence detection; nt, nucleotides.

* Corresponding author. Tel.: +60 97785001; fax: +60 97785006.

E-mail addresses: cpleaw@um.edu.my, chuipinleaw@gmail.com (C.P. Leaw).
}

lack of research regarding the species in this region may explain in part this discrepancy. However, recently, the number of species reported in the Southeast Asian region has increased dramatically compared to the last report in 2010 (Fukuyo et al., 2011), with four new species described from Malaysia: Pseudo-nitzschia batesiana, Pseudo-nitzschia circumpora, Pseudo-nitzschia fukuyoi and Pseudonitzschia lundholmiae (Lim et al., 2012a, 2013). Several studies were undertaken along the coasts of Malaysian Borneo (Lim et al., 2010, 2012a,b,c, 2013) and Peninsular Malaysia (Lim et al., 2012c,d, 2013; Teng et al., 2013). A checklist of Pseudo-nitzschia species along the coasts of Malaysia presented 22 Pseudo-nitzschia spp., including a new morphotype, P. sp. Port Dickson (Teng et al., 2013). These studies revealed high species richness and diversity in the tropics, indicating a wide distribution of Pseudo-nitzschia species, and suggesting more novel species to be uncovered from the region.

In Malaysia, particularly in the Straits of Malacca, harmful algal bloom (HAB) research and monitoring have been undertaken intensively owing to the recent increased frequency of bloom events in the Strait (Lim et al., 2012d). Several HAB species were 